\title{
Contribution of the genetic background to the immune response of broilers vaccinated or challenged with LPAI H9N2
}

\author{
Lonneke Vervelde ${ }^{1}$, Eveline de Geus ${ }^{1}$, Christine Jansen ${ }^{1}$, Dan E Heller ${ }^{2^{*}}$ \\ From International Symposium on Animal Genomics for Animal Health (AGAH 2010) \\ Paris, France. 31 May - 2 June 2010
}

\begin{abstract}
Background: The knowledge on the immune responses to LPAI is limited. The purpose of this study was to investigate the immune responses of two divergently selected lines of broilers, a line responding with high antibody response to antigens $(\mathrm{HH})$, and a line responding with low antibody titers (LL) to antigen.

Methods: Day old chicks from each line were divided in two groups, one vaccinated with inactivated H9N2 vaccine and one non-vaccinated. At 21 days of age all the chicks were challenged with field isolate of H9N2, $1 \times 10^{6.5} \mathrm{ELD}_{50}$ per chick by drops to the eye, nose and beak. Twenty four hours and 14 days post challenge (PC), the chickens were weighed blood spleen and lungs were taken and leukocytes were isolated. The leukocytes were stained with monoclonal antibodies for surface markers and analyzed by flow cytometry. We used Elispot assay to identify the number of antibody producing cells in each of the organs. mRNA was extracted using TRlsol reagent in order to assess the cytokine production level by qRT-PCR using the SYBR green methods.
\end{abstract}

Results: Our results showed that LL-vaccinated group gained more weight than any of the other group. Using IDEXX kit, no antibody titers could be identified in vaccinated chicks 21 days post vaccination while 14 days PC vaccinated $\mathrm{HH}$ chickens demonstrated the highest average antibody titers. LL vaccinated chickens demonstrated higher average antibody titer than non-vaccinated LL. Using the Elispot assay no difference were found between the groups either cells producing IgA, IgM or IgY beside of a high number of IgY producing cells in the lungs of vaccinated $\mathrm{HH}$ birds.

Conclusions: Further data on leukocytes subpopulations using flow cytometry, cytokines production (IFNy, IL-6, IL18, IL-2 and IL-4) isotype specific antibody responses and number and functionality of NK cells are in process.

\section{Background}

Influenza viruses of type A infect humans, horses, swine other mammals and a wide variety of domesticated and wild birds. The reservoir of the virus is considered to be in wild waterfowl. Infection of poultry with AI viruses cause a wide range of clinical signs including mild and severe respiratory disease, producing losses and sometimes severe disease with high morbidity and mortality.

\footnotetext{
* Correspondence: dheller@agri.huji.ac.il

${ }^{2}$ Dept of Animal Sciences, Faculty of Agricultural, Food and Environmental Quality, The Hebrew University of Jerusalem, P.O.Box 12, Rehovot 76100, Israel

Full list of author information is available at the end of the article
}

AI viruses are typically characterized as either being Low Pathogenic Avian Influenza (LPAI), or High pathogenic AI (HPAI) viruses. Numerous vaccines against avian influenza (AI) have been developed and shown to be efficacious, but the number of AIV outbreaks in commercial poultry is reduced but not eradicated. With a greater understanding of the host immune response to the AI infection and vaccination, better control strategies can be developed.

Differences in pathogenicity between species have been observed in galliforme birds in experimental studies with LPAI and HPAI viruses [1]. Differences are also apparent when comparing the immune responses, 
primarily antibody titers, of different species of AI virus infections.

Our knowledge of avian cellular immunology has expanded rapidly in the last decade. It is well accepted that the cellular immune response is important in the defense against many viral infections. However, very little is known about the importance of cellular immunity against AI virus.

The objective of this work was to study the interaction of inactivated LPAI virus vaccine and the challenge with virulent LPAI on the immune system of chickens.

An important part of this project was to analyze the influence of genetic factors on chicken immune responses against LPAI using two divergently selected broiler lines.

These genetically distinct chicken lines identified as high $(\mathrm{HH})$ or low (LL) responders in respect to antibody responses [2,3].

\section{Methods}

Chicks of the HH and LL lines hatched in the Utrecht University facilities. At day old chicks each line was divide into two, half vaccinated and Half non-vaccinated.

Vaccination was performed injecting subcutaneously $0.5 \mathrm{ml}$ of inactivated $\mathrm{A} / \mathrm{IL} / \mathrm{H} 9 \mathrm{~N} 2 / 125$ vaccine $\left(\log _{10} 3.8\right.$ $E_{50}$ ). Non- vaccinated chicks were subcutaneously injected with $0.5 \mathrm{ml}$ PBS. At 21 days of age all the chicks were weighed and bled, and challenged with 0.1 $\mathrm{ml}=\log _{10} 6.5 \mathrm{EID}_{50} \mathrm{H} 9 \mathrm{~N} 2 /$ chick by nose and eyedrops. The serum was used for antibody determination by IDEXX kit.

At 22 days of age (One day post challenge (dpc) for early response), $4 \mathrm{HH}$ non-vaccinated and $4 \mathrm{HH}$ vaccinated, $5 \mathrm{LL}$ non-vaccinated and $5 \mathrm{LL}$ vaccinated were taken, blood spleen and lungs were sampled. At 35 days old (14 dpc for late response) $2 \mathrm{HH}$ non-vaccinated and $4 \mathrm{HH}$ vaccinated, $5 \mathrm{LL}$ non-vaccinated and $5 \mathrm{LL}$ vaccinated chickens were taken, and blood, spleen and lungs were harvested.

\section{Leukocytes isolation}

Blood was taken with anticoagulant (Heparine), diluted by equal volume of PBS at room temperature (RT), and was over layered on Ficoll (GE Healthcare,Uppsala) and centrifuged $20 \mathrm{~min}$ at $2200 \mathrm{rpm}$. The interphase containing the leukocytes was harvested washed twice and finally re-suspended in $5 \mathrm{ml}$ and counted using trypan blue and haemocytometer.

Table 1 Mean body weight (BW) of the 4 experimental groups of chick at $\mathbf{2 1}$ days of age $(\mathbf{g})$

\begin{tabular}{ccccc}
\hline $\begin{array}{c}\mathrm{HH} \text { Non- } \\
\text { vaccinated }\end{array}$ & $\begin{array}{c}\mathrm{HH} \\
\text { Vaccinated }\end{array}$ & $\begin{array}{c}\text { LL Non- } \\
\text { vaccinated }\end{array}$ & $\begin{array}{c}\mathrm{LL} \\
\text { Vaccinated }\end{array}$ \\
\hline BW & 368.7 & 370.3 & 381.5 & 454.8 \\
\hline
\end{tabular}

Table 2 Mean body weight (BW) of the 4 experimental groups of chicken at 35 days of age $(\mathrm{g})$

\begin{tabular}{ccccc}
\hline $\begin{array}{c}\mathrm{HH} \text { Non- } \\
\text { vaccinated }\end{array}$ & $\begin{array}{c}\mathrm{HH} \\
\text { Vaccinated }\end{array}$ & $\begin{array}{c}\text { LL Non- } \\
\text { vaccinated }\end{array}$ & $\begin{array}{c}\mathrm{LL} \\
\text { Vaccinated }\end{array}$ \\
\hline BW & 1152.5 & 1094.0 & 1110.8 & 1351.0 \\
\hline
\end{tabular}

Spleen leukocytes were isolated by removing the capsule and pressing the spleens through cell strainer (BD Falcon, Bedford, MA.). The cells were overlayered on Ficoll (GE Healthcare,Uppsala) and treated as the blood lymphocytes. The cells harvested from the interphase were washed twice (1,300 rpm for $5 \mathrm{~min})$, re-suspended in $20 \mathrm{ml}$ and counted.

Lung leukocytes were isolated by cutting the lungs into small pieces in 6 wells plated. To each well $2 \mathrm{ml}$ of collagenase/DNAse solution was added. The plates were incubated for $30 \mathrm{~min}$ at $37^{\circ} \mathrm{C}$ with $5 \% \mathrm{CO}_{2}$. The lung tissue was pressed through $70 \mathrm{mM}$ cell strainer (BD Falcon, Bedford, MA.). The cells were washed once (1300 rpm for 5 min.), re-suspended in $5 \mathrm{ml} \mathrm{PBS}$ and overlayered on Ficoll, and the interphase collected. The cells were washed twice $(1,300 \mathrm{rpm}$ for $5 \mathrm{~min})$, re-suspended in $5 \mathrm{ml}$ and counted.

\section{Results}

As it can be seen from table 1, LL vaccinated chicks gained more weight than the other 3 experimental groups. By the end of the experiment at 35 days of age LL vaccinated chickens were heavier than the other 3 groups (Table 2.)

No H9N2 specific serum antibody titers could be detected at 21 days of age. At 35 days of age (14 dpc), no antibody titers could be detected in non-vaccinated chickens (Fig.1.), while in the $\mathrm{HH}$ vaccinated chickens

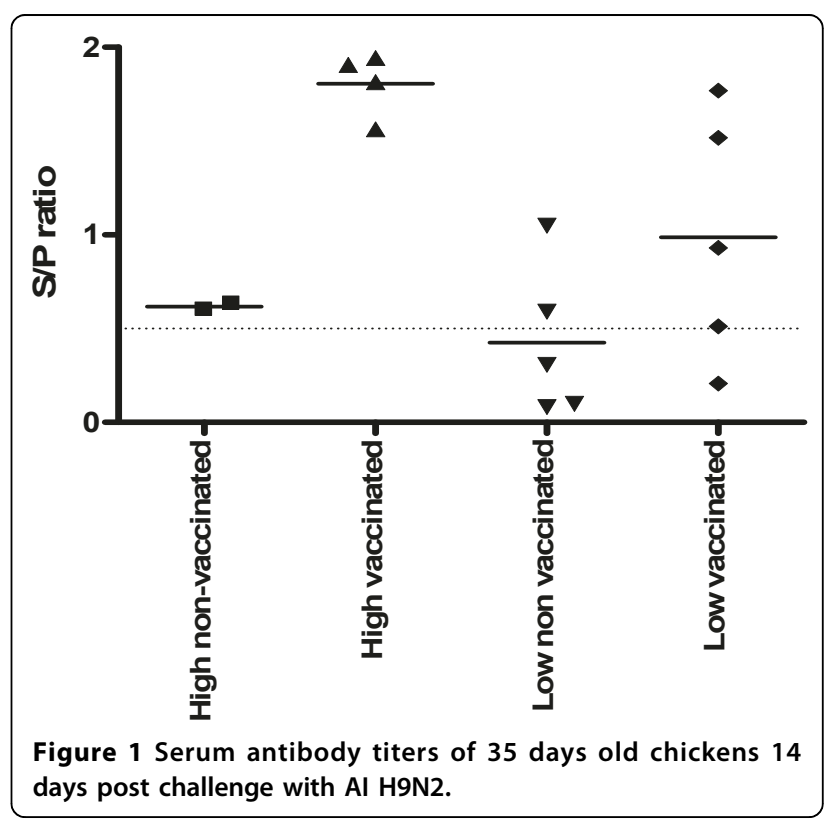


high antibody titers could be detected. In the LL vaccinated group 2 chickens responded with high titer, 2 responded with low and one gave average titer. Using the Elispot assay no difference were found between the groups either cells producing IgA, IgM or IgY beside of a high number of IgY producing cells in the lungs of vaccinated $\mathrm{HH}$ birds (Fig.2.)

\section{Discussion}

Chicks vaccinated at one day of age with an inactivated vaccine did not responded with a measurable titer of antibodies at 21 days of age. A challenge with a field strain of H9N2 resulted in a specific antibody titers in vaccinated chickens only. $\mathrm{HH}$ vaccinated and challenged group responded with High antibody titers but also with a high number of IgY positive cells in the lungs

\section{Acknowledgements}

This article has been published as part of BMC Proceedings Volume 5 Supplement 4, 2011: Proceedings of the International Symposium on Animal Genomics for Animal Health (AGAH 2010). The full contents of the supplement are available online at http://www.biomedcentral.com/1753$6561 / 5$ ?issue $=\$ 4$

\section{Author details}

${ }^{1}$ Dept. Infectious Diseases and Immunology, Faculty Veterinary Medicine, University Utrecht, Yalelaan 1, $3584 \mathrm{CL}$ Utrecht, The Netherlands. ${ }^{2}$ Dept of Animal Sciences, Faculty of Agricultural, Food and Environmental Quality,

The Hebrew University of Jerusalem, P.O.Box 12, Rehovot 76100, Israel.

\section{Competing interests}

The authors declare that they have no competing interests.

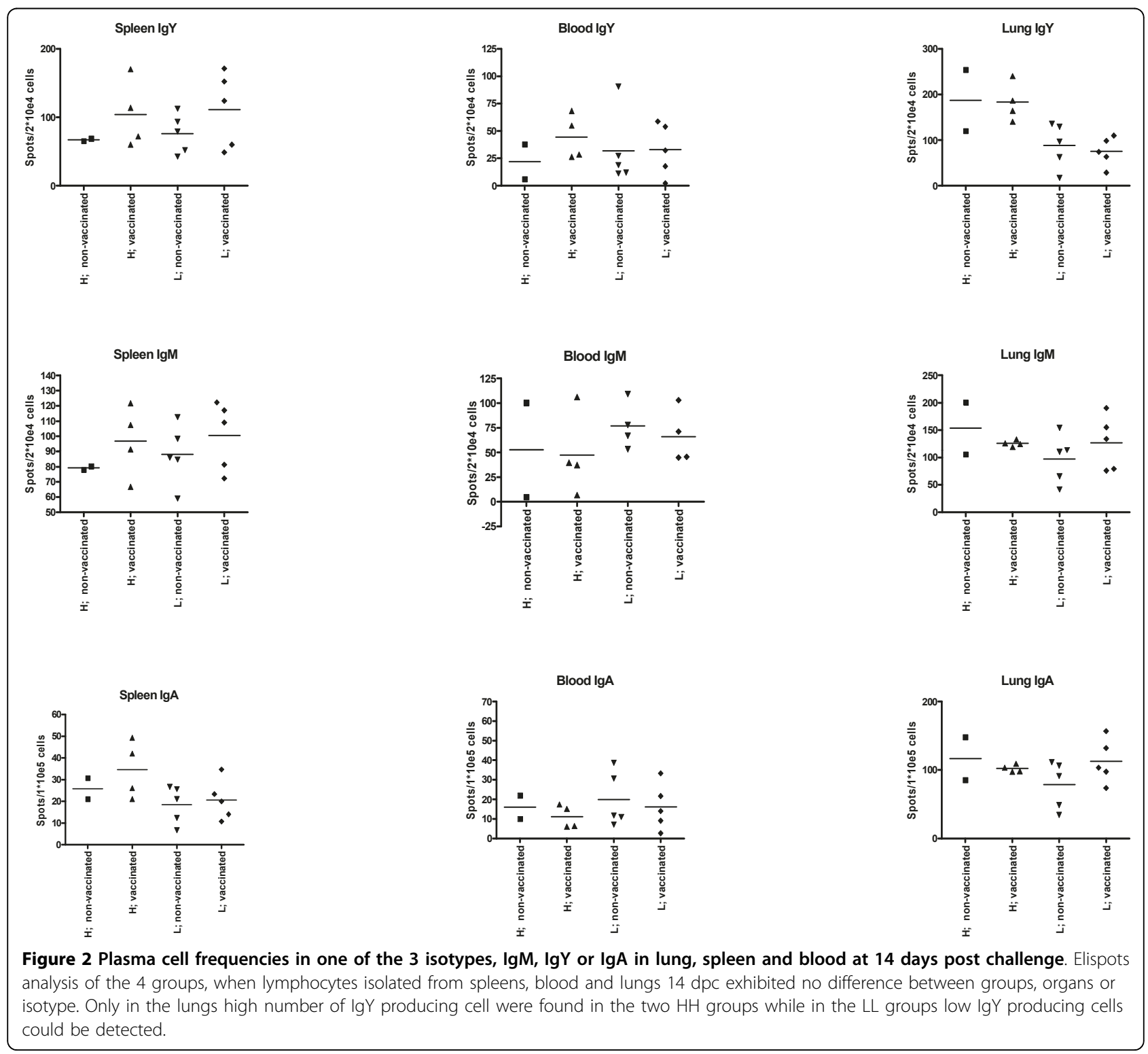




\section{References}

1. Laudert E, Halvorson D, Sivanandan V, Shaw D: Comparative evaluation of tissue trophism characteristics in turkeys and mallard ducks after intravenous inoculation of type A influenza viruses. Avian Dis 1993, 37:773-780.

2. Peleg BA, Heller ED, Pitkovsky J: The ontogeny of the humoral immune response to $E$. coli vaccine and to sheep red blood cells in young chicks. Avian Pathol 1985, 14:471-482.

3. Pitcovski J, Heller ED, Cahaner A, Peleg BA: Selection for early responsiveness of chicks to Escherichia coli and Newcastle disease virus. Poultry Sci 1987, 66:1276-1282.

doi:10.1186/1753-6561-5-S4-S5

Cite this article as: Vervelde et al:: Contribution of the genetic background to the immune response of broilers vaccinated or challenged with LPAI H9N2. BMC Proceedings 2011 5(Suppl 4):S5.

\section{Submit your next manuscript to BioMed Central} and take full advantage of:

- Convenient online submission

- Thorough peer review

- No space constraints or color figure charges

- Immediate publication on acceptance

- Inclusion in PubMed, CAS, Scopus and Google Scholar

- Research which is freely available for redistribution

Submit your manuscript at www.biomedcentral.com/submit
C Biomed Central 